\title{
Competency Gap in the Labor Market: Evidence from Vietnam*
}

\author{
Quan Thai Thuong LE ${ }^{1}$, Tam Ho Dan DOAN², Quyen Le Hoang Thuy To NGUYEN ${ }^{3}$, Doang Thi Phuc NGUYEN ${ }^{4}$ \\ Received: July 03, 2020 Revised: July 19, 2020 Accepted: August 10, 2020
}

\begin{abstract}
The relationship between education and work is of the greatest concern to individuals and society because they are the key drivers of growth and development. In the context of Industry 4.0, labor and educators are facing the challenges of big changes in the workplace. How to prepare undergraduate students for the world of employment has become the most important mission of higher education providers. This paper explored the competency gap in the labor market in Vietnam from the perspective of employees who have been dissatisfied with the current status. First, a qualitative method with the Delphi technique was applied to confirm this consensus in an employees' competency model. Then, the satisfaction level for each competency criterion was explored by applying the advance quantitative method, namely, best non-fuzzy performance approach. Lifelong learning was ranked first, followed by creativity and innovation, foreign languages, expertise and digitalization, adaptability, and finally, organizing and managing ability. Critical thinking and problem-solving were perceived to have the biggest gap. The order of competency satisfaction is useful in explaining the mismatch between education quality and labor market demand. The findings provide valuable guidelines for education managers who seek to bridge the competency gap and improve education quality.
\end{abstract}

Keywords: Competency, Employee Perspective, Education Management, Delphi Technique, Human Resources

JEL Classification Code: A22, C60, J24, M54

\section{Introduction}

Social production forces have been shifting from an economy based on natural resources to a knowledge-

\section{*Acknowledgements:}

The authors acknowledge the Ministry of Education and Training, Vietnam and Ho Chi Minh City Open University, Vietnam, for funding this research.

${ }^{1}$ First Author. Assistant Professor, Director, Office of Cooperation and Research Management, Ho Chi Minh City Open University, Vietnam. Email: quan.Itt@ou.edu.vn

${ }^{2}$ Office of Cooperation and Research Management, Ho Chi Minh City Open University, Vietnam. Email: tam.dhd@ou.edu.vn

${ }^{3}$ Corresponding Author. Assistant Professor, Deputy Director, Office of Cooperation and Research Management, Ho Chi Minh City Open University, Vietnam [Postal Address: 97 Vo Van Tan Street, District 3, Ho Chi Minh City, 724000, Vietnam]

Email: quyen.nlhtt@ou.edu.vn

${ }^{4}$ Lecturer, Faculty of Economics and Public Management, Ho Chi Minh City Open University, Ho Chi Minh City, Vietnam.

Email: doang.ntp@ou.edu.vn

(c) Copyright: The Author(s)

This is an Open Access article distributed under the terms of the Creative Commons Attribution Non-Commercial License (https://creativecommons.org/licenses/by-nc/4.0/) which permits unrestricted non-commercial use, distribution, and reproduction in any medium, provided the original work is properly cited. based economy (Dhahad et al., 2020; Qodim et al., 2019; Ramadhan et al., 2020; Tang, Chang, \& Cheng, 2017; Nguyen \& Bui, 2020). In the current global competitive environment, knowledge has become a major economic resource and possibly a dominant and unique resource to achieve a competitive advantage, and economic competition is an educational competition. The prosperity of the nation depends on the scale and quality of education and training. Education, in general, and higher education, in particular, has become the most important strategic question for any country (Alfita, Kadiyono, Nguyen, Firdaus, \& Wekke, 2019). Higher education has always topped priority owing to its role in creating and shaping the quality of human resources and the foundation for the nation's development. Vietnam is similar to other countries, as there have always been gaps between the quality of education and the expectations of society. Several quality gaps using the perspective of stakeholders have previously been studied. In higher education, stakeholders such as students, employers, teaching or non-teaching staff, authorities, accreditation agencies, and professional workers have different expectations (Mizikaci, 2006; Nguyen, Nguyen, Huynh, \& Nguyen, 2020). In addition, each discipline focuses on features of the gap that 
are important to it. Economists approach productivity when analyzing the gap between the required and actual capability of the employees (Ha \& Luan, 2018; Nguyen, Tran, \& Huynh, 2019; Sparreboom \& Tarvid, 2016). Sociologists explore the determinants of the quality mismatch and link them to social policies (Luksyte \& Spitzmueller, 2011). In the national labor market, the consequences of such ranked gap compared to "competencies," "development," and "creativity" (Schwab, 2018). A variety of techniques to identify the competency gap can be found in the literature (Jüttler \& Schumann, 2019). However, the informative way for educators to understand their students is to ask employed workers who were the learners to evaluate their own competency gap as well as the need for additional training for the labor market (Campbell \& Lee, 1988).

In recent years, the application of artificial intelligence to understand the human thought process, and to apply it to the real environment, has become a trend. Fuzzy logic paved the way for modeling human behavior and mathematically-obscure concepts. This is the method preferred by researchers to solve evaluation issues and make decisions. Nguyen, Nguyen, Nguyen, and Huynh (2019) developed the competency-ranking model of undergraduate employees in Vietnam. Their findings concluded that there were seven dimensions of priority, including, (1) critical thinking and problem-solving; (2) organizing and managing ability; (3) lifelong learning; (4) adaptability; (5) creativity and innovation; (6) expertise and digitalization; and (7) foreign language. With these findings, the importance of skills was ranked, but the level of skills satisfaction, an essential foundation for a higher education strategy, was not defined. In fact, the actual gap in the seven dimensions in education and job demand, as well as those into job training from the perspectives of undergraduate employees, have not been explored. The paper fills this research gap by applying the best non-fuzzy performance approach to explore employees' perspectives on competency achieved in school and demanded by the industry. Additionally, onthe-job training demand was analyzed so that improvements in education can be adopted to shorten the gap between learning and work.

\section{Literature Review}

The competency gap generally refers to a lack of necessary capability to satisfy the job requirements (McGuinness \& Ortiz, 2016; Sari, Muhtarom, Nguyen, Nguyen, \& Ansir, 2020). It can be measured either objectively or subjectively and from the perspective of both employers and employees (Flisi, Goglio, Meroni, Rodrigues, \& Vera-Toscano, 2017; Kwon \& Lee, 2020; Vo et al., 2019). The subjective measure is easy to apply in survey data for each specific context through the potential bias that needs to be considered.
Previous research on this topic has been undertaken from the perspective of the employers. These results have been meaningful for higher education providers who seek to improve their educational programs.

Students understand what skills are demanded in the labor market. However, satisfaction with the level of undergraduate skills may not be sufficient if the same approach is applied. In particular, an error relating to "exact code of occupation" may arise when surveying employers because job titles vary at different companies. This error can be eliminated when surveying employees with direct reference to their current job position. In this study, the above justification led to the application of the subjective approach when measuring the competency gap from the perspective of employees.

The competency criteria were developed based on three pillars: IQ, EQ, and personality traits (Yurdakul, Ker-Dincer, Vural, \& Akinci, 2008). IQ is an indicator of intelligence, which is used to assess intellectual development in four areas: (i) abstract reasoning, (ii) logical reasoning, (iii) language reasoning, and (iv) memory reasoning. IQ incorporates hard skills or the technical aspects of expertise and includes the ability to acquire knowledge. This includes the formation of critical thinking, problem-solving, and the ability to focus. EQ is defined as the ability to monitor emotions both internally and externally, to distinguish and use information that guides thoughts and actions. Thus, emotion and cognition are linked, including soft skills that emphasize personal behavior and manage human relationships. It is foundational for forming important skills that are increasingly in demand in the labor market, such as (1) decisionmaking, (2) time management, (3) adaptation, (4) empathy, (5) stress management, (6) teamwork, (7) communication, (8) presentation, (9) social skills, (10) customer service, (11) anger management, (12) flexibility, (13) explanation, (14) assertiveness, and (15) trust (Deming, 2017). While intelligence and individuality are quite stable, emotional intelligence can be improved continuously.

Moreover, emotional intelligence is considered to be the basis for the formation of four core skills for individual behavior: (i) self-awareness, (ii) self- management, (iii) social awareness, and (iv) social management. Self-awareness and self-management are used to perceive subjective emotions and guiding behaviors. On the other hand, social awareness and social management are concerned with management's aim to understand and manage emotions individually and is the social capacity of each individual. Personality traits are understood as preferences or a tendency to engage in specific types of behavior (Han, 2020; Nguyen \& Ngo, 2020; Vo, Nguyen, \& Le-Hoai, 2019). The personal theory is identified with five essential characteristics, including (i) conscientiousness, (ii) extraversion, (iii) agreeableness, (iv) openness to experience, and (v) neuroticism. Personality traits explain individual competence (Agarwal \& Toshniwal, 
2020; Roberts, Walton, \& Viechtbauer, 2006). It can be said that competency has at its root IQ, EQ, and personality traits. However, the criteria change regularly. For instance, Schwab (2018) reported models of employees' competency in the Industry 4.0 analysis, where automation is dominant. The Vietnamese labor market has witnessed such changes. As a result, the following seven skills have been identified as necessary to prepare undergraduates for a career or job, as shown in Table 1.

\section{Research Methodology}

A test using the Delphi technique qualitative method was conducted to identify and confirm the indicators of the top seven skills currently demanded in the Vietnamese labor market. This is the technique used for consensus achievement (Hsu \& Sandford, 2007; Kembro, Näslund, \& Olhager, 2017). To mobilize the collective intelligence, this technique's principle is based on the proposition that $n+1$ heads are always better than $n$ heads. The Delphi method screens and synthesizes the opinions of experts. Using this technique, experts do not need to meet each other, which helps prevent confrontation or conflicts of personalities and the influence of an influential person in the group of experts (Alazmi \& Al-Kubaisi, 2020). This technique brings optimum economic efficiency, especially when experts are in different locations.

The first step of the Delphi technique is to get expert advice on the options and record the expert's explanation on an issue. Inviting appropriate experts to conduct the survey is an important step for the research result. The next step in the Delphi technique is to edit a survey questionnaire and get it reviewed until reaching the experts' consensus. In principle, this technique does not specify the number of iterations. However, experience has shown that two to three rounds of interviews are sufficient to reach the consensus.

Table 1: Top critical seven skills in the Vietnamese labor market

\begin{tabular}{|c|c|}
\hline Description & Measurement \\
\hline \multirow{4}{*}{ Critical thinking and problem-solving } & Think multi-dimensionally \\
\hline & Analyze and evaluate \\
\hline & Know how to search or aggregate information systematically \\
\hline & Teamwork \\
\hline \multirow{4}{*}{ Organizing and managing ability } & Know the management and organization of work \\
\hline & Apply leadership skills \\
\hline & Cooperate effectively \\
\hline & High discipline spirit \\
\hline \multirow[b]{2}{*}{ Lifelong learning } & Constantly learn and update knowledge \\
\hline & $\begin{array}{l}\text { Know how to self-study effectively and proactively build the learning } \\
\text { goals }\end{array}$ \\
\hline \multirow{4}{*}{ Adaptability } & Know how to work in an interdisciplinary and multicultural environment \\
\hline & Flexibility \\
\hline & Think positively \\
\hline & Apply known knowledge under new circumstances \\
\hline \multirow{2}{*}{ Creativity and Innovation } & Dare to explore, discover and test new ideas \\
\hline & Think out of the box \\
\hline \multirow{3}{*}{ Expertise and digitalization } & Ready to apply science and technology \\
\hline & Capture and update new knowledge about IT \\
\hline & Apply IT knowledge to solve tasks \\
\hline \multirow{4}{*}{ Foreign language } & Basic knowledge \\
\hline & Conversant \\
\hline & Proficient \\
\hline & Fluent \\
\hline
\end{tabular}


In this study, two rounds of interviews were performed using unstructured interviews and individually-structured surveys, respectively. In the first round, 20 experts who met four criteria - (i) knowledge of and experience with human resources, (ii) willingness to participate in the interview. (iii) availability for interviews, and (iv) effective communication skills - were invited to join the interview to determine the appropriate measure of competency in the context of Vietnam (Skulmoski, Hartman, $\&$ Krahn, 2007). Keywords with word cloud technology were applied to analyze the data from the interviews. In the second round, the structural questionnaires were sent to participants to collect data on the consensus indicators of competency. The descriptive statistical method was then used to analyze the satisfaction levels with the graduates' perspective on their competencies. The data from 624 undergraduate employees in fields currently experiencing shortages of skilled labor in Ho Chi Minh City, Vietnam, was analyzed. Finally, the best nonfuzzy performance approach was adopted to determine the weight of each skill gap. It is the method that uses mathematical logic to solve the problem of inaccurate input data values, in order to reach a precise conclusion (Luong, Tran, \& Nguyen, 2018; Nguyen, Vu, Van Nguyen, Le, \& Vo, 2019; Phong \& Quyen, 2017). For defuzzified the fuzzy weights, we applied the following CoA method:

$$
B_{w_{i}}=\left[\left(Z_{w_{i}}-X_{w_{i}}\right)+\left(Y_{w_{i}}-X_{w_{i}}\right)\right] / 3+X_{w_{i}}
$$

where $B_{w_{i}}$ is the best non-fuzzy performance value.

\section{Results and Discussion}

Table 2 summarized the research sample. In the experts' survey sample, the percentage of male $(60 \%)$ and female $(40 \%)$ was not substantially different. The majority of experts $(65 \%)$ was over the age of 50 and had doctorates $(80 \%)$, and meet the criteria of knowledge and experience. Also, the field of expertise of the experts was of interest because competency gaps depend on the context. In the case of the employees, the percentages of males and females were also quite similar. Most of them $(97.43 \%)$ were under the age of 30 and held the position of junior staff (97.4\%). The survey focused on employees in seven fields that have experienced severe skill shortages in Ho Chi Minh City, Vietnam.

The Delphi result, shown in Table 3, confirmed the importance of the skills in the competency model. In general, the scales had average values from 7.00 to 9.25. The most typical value (median) was from 7 to 10 ; the most common value (mode) in the competency model was 6,7,8,9, and 10. The standard deviation (SD) ranges from 0.45 to 1.29 , or less than 1.5, which met the requirement of consensus (Christie \& Barela, 2005; de Jesus, Antunes, Santos, \& Mendonça, 2019). For the quartile range, values were in the range of $0.25-2$, less than 2.5 , satisfying consensus requirement (Kittell-Limerick, 2005).
Table 2: Top key seven skills in the Vietnamese labor market

\begin{tabular}{|c|c|c|c|}
\hline \multicolumn{2}{|l|}{ Description } & Quantity & Percentage \\
\hline \multicolumn{4}{|c|}{ Experts' information } \\
\hline \multirow{2}{*}{ Gender } & Male & 12 & 60 \\
\hline & Female & 8 & 40 \\
\hline \multirow{3}{*}{ Age } & $30-39$ & 2 & 10 \\
\hline & $40-49$ & 5 & 25 \\
\hline & $>50$ & 13 & 65 \\
\hline \multirow{2}{*}{$\begin{array}{l}\text { Education } \\
\text { level }\end{array}$} & Master & 4 & 20 \\
\hline & PhD & 16 & 80 \\
\hline \multirow{3}{*}{ Experience } & HR recruiters & 4 & 7 \\
\hline & HR researcher & 2 & 3 \\
\hline & Others & 6 & 10 \\
\hline \multicolumn{4}{|c|}{ Graduate employees' information } \\
\hline \multirow{2}{*}{ Gender } & Male & 306 & 49 \\
\hline & Female & 318 & 51 \\
\hline \multirow{3}{*}{ Age } & $22-25$ & 169 & 27.08 \\
\hline & $26-30$ & 439 & 70.35 \\
\hline & $31-36$ & 16 & 2.57 \\
\hline \multirow{2}{*}{ Position } & Junior staff & 608 & 97.40 \\
\hline & Senior staff & 16 & 2.60 \\
\hline \multirow{7}{*}{ Major } & $\begin{array}{l}\text { Information } \\
\text { technology }\end{array}$ & 106 & 17.00 \\
\hline & $\begin{array}{l}\text { Economics or } \\
\text { commerce }\end{array}$ & 202 & 32.40 \\
\hline & Transportation & 43 & 6.90 \\
\hline & $\begin{array}{l}\text { Finance, } \\
\text { banking, or } \\
\text { insurance }\end{array}$ & 79 & 12.70 \\
\hline & Health service & 55 & 8.80 \\
\hline & Tourism & 44 & 7.10 \\
\hline & Others & 95 & 15.20 \\
\hline
\end{tabular}


Table 3: The Delphi result

\begin{tabular}{|l|c|c|c|c|c|c|c|}
\hline Description & Median & Q1 & Q3 & Q= Q3-Q1 & Mode & Average & SD \\
\hline Adaptability & 9.00 & 8.00 & 9.00 & 1.00 & 9.00 & 8.67 & 0.89 \\
\hline $\begin{array}{l}\text { Organizing and } \\
\text { managing ability }\end{array}$ & 9.00 & 8.75 & 9.00 & 0.25 & 9.00 & 8.75 & 0.45 \\
\hline Lifelong learning & 9.00 & 8.00 & 9.25 & 1.25 & 9.00 & 8.75 & 1.06 \\
\hline $\begin{array}{l}\text { Critical thinking } \\
\text { and problem } \\
\text { solving }\end{array}$ & 10.0 & 8.75 & 10.0 & 1.25 & 10.00 & 9.25 & 1.06 \\
\hline Foreign language & 7.00 & 6.00 & 8.00 & 2.00 & 6.00 & 7.00 & 1.21 \\
\hline $\begin{array}{l}\text { Expertise and } \\
\text { digitalization }\end{array}$ & 7.50 & 7.00 & 9.00 & 2.00 & 7.00 & 7.75 & 1.29 \\
\hline $\begin{array}{l}\text { Creativity and } \\
\text { innovation }\end{array}$ & 8.00 & 8.00 & 9.00 & 1.00 & 8.00 & 8.17 & 0.72 \\
\hline
\end{tabular}

Table 4: Self-rated competency according to the undergraduate employees

\begin{tabular}{|l|c|c|c|c|c|}
\hline Description & Mean & Median & Mode & SD & Variance \\
\hline Lifelong learning & 6.53 & 7.00 & 7.00 & 1.705 & 2.908 \\
\hline Creativity and innovation & 6.44 & 7.00 & 7.00 & 2.568 & 6.596 \\
\hline Expertise and digitalization & 6.47 & 7.00 & 7.00 & 1.830 & 3.349 \\
\hline Adaptability & 6.19 & 7.00 & 7.00 & 1.806 & 3.261 \\
\hline Critical thinking and problem solving & 6.14 & 6.00 & 7.00 & 1.791 & 3.207 \\
\hline Foreign language & 6.41 & 6.00 & 7.00 & 1.769 & 1.746 \\
\hline Organizing and managing ability & 5.99 & 6.00 & 6.00 & 1.746 & 3.050 \\
\hline
\end{tabular}

The findings in this table confirmed the recent trends in skill demand in Vietnamese labor under Industry 4.0, as well as send a signal on the deficiencies in education quality in higher education. Vietnamese education has a long-term plan for improving foreign-language acquisition, especially for English and IT for learners (Nguyen, Nguyen, \& Huynh, 2019; Steel, 2017; Vu et al., 2019). The survey data have confirmed several achievements of Vietnamese higher education in building learner capacity in response to the labor market response. As for foreign-language (English) acquisition, 20\% of the undergraduates satisfied the employers' requirement for recruitment. The self-rated level of informants at the basic and advanced level of IT literacy was $74 \%$ and $21.6 \%$, respectively. Data on self-rated competency of the undergraduate employees revealed weakness in three key skills: organizing and managing ability, critical thinking and problem solving, and adaptability, as shown in Table 4.

This description suggested the justification for the best non-fuzzy performance approach result presented in Table 5. Compared to the previous research on employers' viewpoint regarding undergraduate competency in the labor market, the satisfaction level results in Table 4 explain the gap in labor market supply and demand. Employers had their highest priority, critical thinking, and problem-solving, followed by organizing and managing ability and adaptability. Duong, Nguyen, and Nguyen (2020) have concluded that these
Table 5: The rank of employees' satisfaction level

\begin{tabular}{|l|c|}
\hline Description & $\begin{array}{c}\text { The rank of employees' } \\
\text { satisfaction level }\end{array}$ \\
\hline Lifelong learning & 1 \\
\hline Creativity and innovation & 2 \\
\hline Foreign language & 3 \\
\hline Expertise and digitalization & 4 \\
\hline Adaptability & 5 \\
\hline $\begin{array}{l}\text { Organizing and managing } \\
\text { ability }\end{array}$ & 6 \\
\hline $\begin{array}{l}\text { Critical thinking and problem } \\
\text { solving }\end{array}$ & 7 \\
\hline
\end{tabular}

capabilities had achieved the lowest satisfaction levels. Critical thinking and problem-solving refer to the ability to analyze, interpret, evaluate, summarize, and synthesize information. These were the top skills required by the labor market. With the rapid change of technology of Industry 4.0, creativity and innovation also boost productivity, which is the goal of employers, in particular, and economy, in general (Kim, 2019; Kozlova et al., 2019). Creativity has relevance primarily when it is linked to adaptability and knowledge. It was also a capacity that makes a difference for undergraduate employees. 
A clear trend in today's development is automation and artificial intelligence (AI), in which most regular, repetitive tasks are to be performed by robots (Ramakrishnan, Shabbir, Kassim, Nguyen, \& Mavaluru, 2020; Saragih, Chin, Setyawasih, Nguyen, \& Shankar, 2019; Ulfa, Saputra, Yuswardi, \& Nguyen, 2020). Thus, the routine and less value-added work have been at risk of being replaced by automation. The McKinsey report showed a significant decline in the labor force, about $50 \%$ with the rise of automation (Bughin et al., 2017). However, with this loss of jobs, new jobs have also been created (i.e., $8-10 \%$ of the labor force will do new, unprecedented jobs). The World Economic Forum has forecast that the children going to school today will take on jobs that have not been created yet. According to a survey made by the workforce, workers need to be equipped with skills superior to those of the new machines, such as communication, ability to cooperate, critical thinking, and problem-solving.

Besides, adaptability is also critical. In short, every industrial revolution, even if it brings disruptions, also creates opportunity. The invention of the steam engine, for example, reduced the need for human muscular strength, the canal system, and horsepower, but it ushered in a new era with manufacturing, the road system, rails and waterways, and new roads for the modern. The invention of the internal combustion engine and electricity created social disruption when workers had to move from farms to cities, yet it was these innovations that brought the world an era of commodity production. Automation, along with personal computers and information technology, has eliminated jobs such as phone operators and typists, reduced the number of production workers and administrative clerks, but it has opened the Internet era. With the Industry 4.0 revolution, the connection between technology and social progress is being tested, and we have the right to be optimistic about a new and useful era that will be opened (Muruganantham et al., 2019;). However, we must be prepared to accept the impact of this revolution. Stakeholders need to build and develop an individual's capacity to control all situations.

Stabback (2016) has proved the essential role of curriculum in enabling education quality, in particular, articulating competencies. It provides a bridge between education and labor market development. For learners, their life opportunities can be reached through a quality curriculum. Therefore, it is worth addressing its contribution to labor force competencies. In Vietnam, the national education qualification framework is a guideline for the educational program at each level. The role of various courses in educational programs from the perspective of undergraduate employees is summarized in Table 6.
Table 6: Course contribution to the competency model

\begin{tabular}{|c|c|c|c|c|}
\hline & Min & Max & Mean & SD \\
\hline \multicolumn{5}{|l|}{ Lifelong learning } \\
\hline Political science & 0 & 10 & 2.91 & 2.404 \\
\hline Foreign language & 0 & 10 & 5.53 & 2.848 \\
\hline Information technology & 0 & 10 & 5.52 & 2.719 \\
\hline Basic courses & 0 & 10 & 5.49 & 2.121 \\
\hline Professional courses & 0 & 10 & 6.36 & 2.06 \\
\hline Internship & 0 & 10 & 5.78 & 2.487 \\
\hline Physical activities & 0 & 10 & 3.64 & 2.747 \\
\hline \multicolumn{5}{|c|}{ Creativity and innovation } \\
\hline Political science & 0 & 10 & 2.56 & 2.524 \\
\hline Foreign language & 0 & 10 & 5.22 & 3.073 \\
\hline Information technology & 0 & 10 & 5.28 & 2.979 \\
\hline Basic courses & 0 & 10 & 5.52 & 2.279 \\
\hline Professional courses & 0 & 10 & 5.67 & 2.67 \\
\hline Internship & 0 & 10 & 5.33 & 2.902 \\
\hline Physical activities & 0 & 10 & 3.14 & 2.823 \\
\hline \multicolumn{5}{|l|}{$\begin{array}{l}\text { Expertise and } \\
\text { digitalization }\end{array}$} \\
\hline Political science & 0 & 10 & 4.48 & 2.547 \\
\hline Foreign language & 0 & 10 & 6.27 & 2.127 \\
\hline Information technology & 0 & 10 & 7.01 & 1.965 \\
\hline Basic courses & 0 & 10 & 6.09 & 1.997 \\
\hline Professional courses & 0 & 10 & 6.67 & 1.915 \\
\hline Internship & 0 & 10 & 6.71 & 2.073 \\
\hline Physical activities & 0 & 10 & 4.38 & 2.72 \\
\hline \multicolumn{5}{|l|}{ Adaptability } \\
\hline Political science & 0 & 10 & 2.69 & 2.699 \\
\hline Foreign language & 0 & 10 & 5.29 & 2.971 \\
\hline Information technology & 0 & 10 & 6.41 & 2.054 \\
\hline Basic courses & 0 & 10 & 6.09 & 1.941 \\
\hline Professional courses & 0 & 10 & 6.69 & 1.897 \\
\hline Internship & 0 & 10 & 6.75 & 2.101 \\
\hline Physical activities & 0 & 10 & 4.6 & 2.657 \\
\hline \multicolumn{5}{|l|}{$\begin{array}{l}\text { Critical thinking and } \\
\text { problem solving }\end{array}$} \\
\hline Political science & 0 & 10 & 4.55 & 2.568 \\
\hline Foreign language & 0 & 10 & 6.1 & 2.18 \\
\hline Information technology & 0 & 10 & 6.23 & 2.069 \\
\hline Basic courses & 0 & 10 & 6.08 & 1.999 \\
\hline
\end{tabular}




\begin{tabular}{|l|l|l|l|l|}
\hline & Min & Max & Mean & SD \\
\hline Professional courses & 0 & 10 & 6.81 & 1.922 \\
\hline Internship & 0 & 10 & 5.22 & 3.011 \\
\hline Physical activities & 0 & 10 & 3.28 & 2.897 \\
\hline Foreign language & & & & \\
\hline Political science & 0 & 10 & 2.4 & 2.552 \\
\hline Foreign language & 0 & 10 & 6.85 & 2.579 \\
\hline Information technology & 0 & 10 & 6.32 & 2.13 \\
\hline Basic courses & 0 & 10 & 5.85 & 2.118 \\
\hline Professional courses & 0 & 10 & 6.52 & 2.083 \\
\hline Internship & 0 & 10 & 6.51 & 2.115 \\
\hline Physical activities & 0 & 10 & 4.36 & 2.786 \\
\hline $\begin{array}{l}\text { Organizing and managing } \\
\text { ability }\end{array}$ & & & & \\
\hline Political science & 0 & 10 & 4.75 & 2.603 \\
\hline Foreign language & 0 & 10 & 6.02 & 2.183 \\
\hline Information technology & 0 & 10 & 6 & 2.211 \\
\hline Basic courses & 0 & 10 & 5.85 & 2.13 \\
\hline Professional courses & 0 & 10 & 6.56 & 1.955 \\
\hline Internship & 0 & 10 & 6.52 & 2.099 \\
\hline Physical activities & 0 & 10 & 3.2 & 2.974 \\
\hline
\end{tabular}

In general, political science and physical activities were considered the least important for the building industry. This finding conforms to the tendency in the criticism of political science in general around the world (Ahmad, 2019). Political science often places a heavy emphasis on theory while ignoring practical skills. Thus, providers of higher education have been recommending to be more focused on teaching practical skills to increase the value of the course in the employability of the students. The low ranking of physical activities, however, is incongruent with the needs of the current job setting. They are promoting health and physical activities to empower learners throughout their lifespans. This suggests that there is a lack of effective programs and methods (Haible et al., 2019).

Disciplinary courses and internships make the most significant contributions to undergraduate competency development. The courses in the major can help in deepening learners' knowledge. This principle of quality education is to get knowledge by doing and to do by knowing. Internships offer an important alternative to the traditional educational program. It serves the purpose of helping accumulate practical experience to prepare undergraduate learners to enter the labor force. Learners' competency is built in an internship by enhancing social capital through networking with professionals and potential employers and bridging the gap between theory and practice (Hurd \& Schlatter, 2007; P. V. Nguyen, Nguyen, Nguyen, \& Huynh, 2016; Nguyen, Nguyen, Nguyen, \& Huynh, 2019; Quyen, Nguyen, \& Huynh, 2017). However, the organization of practical internships is essential. Success relies on a combination of the student intern, university supervisor, and agency supervisor.

Foreign-language study, information technology, and basic courses play a moderate role even though they are considered the foundation for a higher education program. The importance of foreign language skills is undebatable, especially with the increased mobility of the labor market (Glaesser, 2019). However, Vietnam has several shortcomings that hinder the development of foreign languages, including that insufficient time is allocated to language study, and class size tends to be too large (Nguyen, Fehring, \& Warren, 2015). The problem for information technology is similar to that of language study, with the quality of the facilities along with the size of the class were two critical barriers to learners' accumulation of practical knowledge.

\section{Conclusions}

Competence is the key to every individual's success in his and her career path. Therefore, developing the capacity of human resources is a major goal of national education. The findings confirm the importance of both soft skills and technical development. Moreover, the satisfaction level with their competency from the perspective of the employees is reflected in the deficiency in education quality. The analysis of course contributions to the competency model highlights the roles of internships, extra-curricular activities, and active learning. These findings are important for educational professionals to make changes and adjust the curriculum and teaching methods timely. The research applied qualitative and quantitative analysis techniques to bridge the gap in employee ability to work. Moreover, errors concerning "the exact code of occupation" may be eliminated because the employees directly refer to the jobs they currently do. However, the employees' self-evaluation does potentially suffer from either under- or over-confidence in their evaluation of skill proficiency.

\section{References}

Agarwal, A., \& Toshniwal, D. (2020). Identifying leadership characteristics from social media data during natural hazards using personality traits. Scientific Reports, 10(1). https://doi. org/10.1038/s41598-020-59086-0

Ahmad, T. (2019). Improving political science degree programmes in the twenty-first century. Review of Economics and Political Science. [In Press] https://doi.org/10.1108/REPS-02-20190023 
Alazmi, M. S., \& Al-Kubaisi, H. S. (2020). School principals' perceptions on the diversification of school financing sources: A study using Delphi method. Management in Education, 34(3), 94-106. https://doi.org/10.1177/0892020619897372

Alfita, L., Kadiyono, A. L., Nguyen, P. T., Firdaus, W., \& Wekke, I. S. (2019). Educating the external conditions in the educational and cultural environment. International Journal of Higher Education, 8(8), 34-38. https://doi.org/10.5430/ijhe.v8n8p34

Bughin, J., Hazan, E., Ramaswamy, S., Chui, M., Allas, T., Dahlström, P., \& Trench, M. (2017). Artificial intelligence: The next digital frontier. McKinsey Global Institute Study. McKinsey Global Institute, 1-80. Retrieved April 20, 2020 from: http://www.odbms.org/2017/08/artificial-intelligencethe-next-digital-frontier-mckinsey-global-institute-study/

Campbell, D. J., \& Lee, C. (1988). Self-appraisal in performance evaluation: Development versus evaluation. Academy of Management Review, 13(2), 302-314.

Christie, C. A., \& Barela, E. (2005). The Delphi technique as a method for increasing inclusion in the evaluation process. Canadian Journal of Program Evaluation, 20(1), 105-122.

De Jesus, A., Antunes, P., Santos, R., \& Mendonça, S. (2019). Eco-innovation pathways to a circular economy: Envisioning priorities through a Delphi approach. Journal of Cleaner Production, 228, 1494-1513. https://doi.org/10.1016/j. jclepro.2019.04.049

Deming, D. J. (2017). The growing importance of social skills in the labor market. Quarterly Journal of Economics, 132(4), 1593-1640. https://doi.org/10.1093/qje/qjx022

Dhahad, H. A., Hussen, H. M., Nguyen, P. T., Ghaebi, H., \& Ashraf, M. A. (2020). Thermodynamic and thermoeconomic analysis of innovative integration of kalina and absorption refrigeration cycles for simultaneously cooling and power generation. Energy Conversion and Management, 203, 112241. https://doi. org/10.1016/j.enconman.2019.112241

Flisi, S., Goglio, V., Meroni, E. C., Rodrigues, M., \& Vera-Toscano, E. (2017). Measuring occupational mismatch: Overeducation and overskill in Europe - evidence from PIAAC. Social Indicators Research, 131(3), 1211-1249. https://doi. org/10.1007/s11205-016-1292-7

Glaesser, J. (2019). Competence in educational theory and practice: A critical discussion. Oxford Review of Education, 45(1), 70-85.

Ha, N. M., \& Luan, N. V. (2018). The effect of employers' attraction and social media on job application attention of senior students at pharmaceutical universities in Vietnam. International Journal of Business and Society, 19(2), 473-491.

Haible, S., Volk, C., Demetriou, Y., Höner, O., Thiel, A., Trautwein, U., \& Sudeck, G. (2019). Promotion of physical activity-related health competence in physical education: Study protocol for the gekos cluster randomized controlled trial. BMC Public Health, 19(1), 1-15.
Han, J. H. (2020). The effects of personality traits on subjective well-being and behavioral intention associated with serious leisure experiences. Journal of Asian Finance, Economics and Business, 7(5), 167-176. https://doi.org/10.13106/jafeb.2020. vol7.no5.167

Hsu, C. C., \& Sandford, B. A. (2007). The Delphi technique: Making sense of consensus. Practical Assessment, Research and Evaluation, 12(10), 1-8.

Hurd, A. R., \& Schlatter, B. E. (2007). Establishing cooperative competency-based internships for parks and recreation students. Journal of Physical Education, Recreation \& Dance, 78(4), 31-47.

Jüttler, M., \& Schumann, S. (2019). Is economics a man's business? Exploring the long-term effects of the gender gap in economic competencies at the upper secondary level on students' choice to study economics at university. Citizenship, Social and Economics Education, 18(3), 177-197. https://doi. org/10.1177/2047173419885628

Kembro, J., Näslund, D., \& Olhager, J. (2017). Information sharing across multiple supply chain tiers: A Delphi study on antecedents. International Journal of Production Economics, 193, 77-86. https://doi.org/10.1016/j.ijpe.2017.06.032

Kim, J. E. (2019). The impact of creative role identity and creative self-efficacy on employee creativity in the hotel business. Journal of Asian Finance, Economics and Business, 6(2), 123-133. https://doi.org/10.13106/jafeb.2019.vol6.no2.123

Kittell-Limerick, P. (2005). Perceived barriers to completion of the academic doctorate: A Delphi study: Commerce, TX: Texas A\&M University-Commerce.

Kozlova, A. Y., Samsonova, A. N., Tumanov, D. Y., Nguyen, P. T., To Nguyen, Q. L. H. T., \& Huynh, V. D. B. (2019). The development of children's giftedness in creative self-realization: Conceptual thesis. International Journal of Psychosocial Rehabilitation, 23(1), 28-36. https://doi.org/10.37200/ijpr/ v23i1/pr190210

Kwon, Y., \& Lee, J. (2020). Demographic faultlines in groups: The curvilinearly moderating effects of task interdependence. Journal of Asian Finance, Economics and Business, 7(3), 311-322. doi:10.13106/jafeb.2020.vol7.no3.311

Lee, J. W. (2020). Big data strategies for government, society and policy-making. The Journal of Asian Finance, Economics and Business, 7(7), 475-487. https://doi.org/10.13106/jafeb.2020. vol7.no7.475

Luksyte, A., \& Spitzmueller, C. (2011). Overqualified women: What can be done about this potentially bad situation? Industrial and Organizational Psychology, 4(2), 256-259.

Luong, D. L., Tran, D. H., \& Nguyen, P. T. (2018). Optimizing multi-mode time-cost-quality trade-off of construction project using opposition multiple objective difference evolution. International Journal of Construction Management, 01-13. https://doi.org/10.1080/15623599.2018.1526630 
McGuinness, S., \& Ortiz, L. (2016). Skill gaps in the workplace: Measurement, determinants and impacts. Industrial Relations Journal, 47(3), 253-278.

Mizikaci, F. (2006). A systems approach to program evaluation model for quality in higher education. Quality Assurance in Education, 14(1), 37-53. https://doi. org/10.1108/09684880610643601

Muruganantham, A., Nguyen, P. T., Lydia, E. L., Shankar, K., Hashim, W., \& Maseleno, A. (2019). Big data analytics and intelligence: A perspective for health care. International Journal of Engineering and Advanced Technology, 8(6 Special Issue), 861-864. https://doi.org/10.35940/ijeat.F1162.0886S19

Nguyen, H. M., \& Ngo, T. T. (2020). Psychological capital, organizational commitment and job performance: A case in Vietnam. Journal of Asian Finance, Economics and Business, 7(5), 269-278. https://doi.org/10.13106/jafeb.2020.vol7. no5.269

Nguyen, H. T., Fehring, H., \& Warren, W. (2015). EFL teaching and learning at a Vietnamese university: What do teachers say? English Language Teaching, 8(1), 31-43.

Nguyen, M. H., Tran, B. T., \& Huynh, L. T. (2019). Relation between employees and customers affects to the positive word of mouth through customer satisfaction. Journal of Distribution Science, 17(6), 65-75. doi:10.15722/JDS.17.6.201906.65

Nguyen, M. H., \& Bui, H. N. (2020). Revisiting the relationship between energy consumption and economic growth nexus in vietnam: New evidence by asymmetric ardl cointegration. Applied Economics Letters, 27(15), 75-80. https://doi.org/10.1 080/13504851.2020.1789543

Nguyen, P. T., Vu, N. B., Van Nguyen, L., Le, L. P., \& Vo, K. D. (2019). The application of fuzzy analytic hierarchy process $(F-A H P)$ in engineering project management. The 2018 IEEE 5th International Conference on Engineering Technologies and Applied Sciences, ICETAS 2018.

Nguyen, P. V., Nguyen, P. T., Nguyen, Q. L. H. T. T., \& Huynh, V. D. B. (2016). Calculating weights of social capital index using analytic hierarchy process. International Journal of Economics and Financial Issues, 6(3), 1189-1193.

Nguyen, Q. L. H. T. T., Nguyen, P. T., \& Huynh, V. D. B. (2019). Roles of e-learning in higher education. Journal of Critical Reviews, 6(4), 7-13. https://doi.org/10.22159/jcr.06.04.02

Nguyen, Q. L. H. T. T., Nguyen, P. T., Huynh, V. D. B., \& Nguyen, L. T. (2020). Application chang's extent analysis method for ranking barriers in the e-learning model based on multistakeholder decision making. Universal Journal of Educational Research, 8(5), 1759-1766. https://doi.org/10.13189/ ujer.2020.080512

Nguyen, Q. L. H. T. T., Nguyen, P. V., Nguyen, P. T., \& Huynh, V. D. B. (2019). Using fuzzy logic to develop employees' competency ranking model. The Journal of Social Sciences Research, 5(4), 888-891.

Nguyen, Q. L. H. T. T., Van Nguyen, P., Nguyen, P. T., \& Huynh, V. D. B. (2019). Using fuzzy logic to develop employees competency ranking model. The Journal of Social Sciences Research, 5(4), 888-891.

Phong, N. T., \& Quyen, N.L.H.T.T. (2017). Application fuzzy multiattribute decision analysis method to prioritize project success criteria. In: AIP Conference Proceedings 1903, 070011(2017). https://doi.org/10.1063/1.5011580

Qodim, H., Herningsih, Nguyen, P. T., Nguyen, Q. L. H. T. T., \& Toding, A. (2019). Educating the information integration using contextual knowledge and ontology merging in advanced levels. International Journal of Higher Education, 8(8), 24-29. https://doi.org/10.5430/ijhe.v8n8p24

Quyen, N. L. H. T. T., Nguyen, P. T., \& Huynh, V. D. B. (2017). Prioritization of social capital indicators using extent analysis method. International Journal of Advanced and Applied Sciences, 4(10), 54-57.

Ramadhan, M. C., Sinaulan, R. L., Maryano, Hartati, S., \& Nguyen, P. T. (2020). Regulation and digital economy. Journal of Environmental Treatment Techniques, 8(1), 237-240.

Ramakrishnan, J., Shabbir, M. S., Kassim, N. M., Nguyen, P. T., \& Mavaluru, D. (2020). A comprehensive and systematic review of the network virtualization techniques in the iot. International Journal of Communication Systems, 33(7), 01-19. https://doi. org/10.1002/dac.4331

Roberts, B. W., Walton, K. E., \& Viechtbauer, W. (2006). Patterns of mean-level change in personality traits across the life course: A meta-analysis of longitudinal studies. Psychological Bulletin, 132(1), 1-25. https://doi.org/10.1037/0033-2909.132.1.1

Saragih, M. G., Chin, J., Setyawasih, R., Nguyen, P. T., \& Shankar, K. (2019). Machine learning methods for analysis fraud credit card transaction. International Journal of Engineering and Advanced Technology, 8(6 Special issue), 870-874. https://doi. org/10.35940/ijeat.F1164.0886S19

Sari, Y., Muhtarom, A., Nguyen, Q. L. H. T. T., Nguyen, P. T., \& Ansir. (2020). Predictors of job performance: Moderating role of conscientiousness. International Journal of Innovation, Creativity and Change, 11(6), 135-152. http://eprints.ulm. ac.id/9558/1/11610_Sari_2020_E_R.pdf

Schwab, K. (2018). The global competitiveness report 2018. Cologny, Switzerland: The World Economic Forum.

Skulmoski, G. J., Hartman, F. T., \& Krahn, J. (2007). The Delphi method for graduate research. Journal of Information Technology Education: Research, 6(1), 1-21.

Sparreboom, T., \& Tarvid, A. (2016). Imbalanced job polarization and skills mismatch in Europe. Journal for Labour Market Research, 49(1), 15-42. https://doi.org/10.1007/s12651-0160196-y

Stabback, P. (2016). What makes a quality curriculum? In-progress reflection no. 2 on "current and critical issues in curriculum and learning". Geneva, Switzerland: UNESCO International Bureau of Education.

Steel, C. H. (2017). Enabling Effective Mobile Language Learning: Students' Perspectives, Wants and Needs. In: Murphy A., Farley 
H., Dyson L., \& Jones H. (Eds), Mobile Learning in Higher Education in the Asia-Pacific Region (pp. 523-539). Education in the Asia-Pacific Region: Issues, Concerns and Prospects, Vol 40. Springer, Singapore. https://doi.org/10.1007/978-981-104944-6 25

Tang, A. D., Chang, M. L., \& Cheng, C. F. (2017). Enhancing knowledge sharing from self-initiated expatriates in Vietnam: The role of internal marketing and work-role adjustment in an emerging economy. Asia Pacific Business Review, 23(5), 677-696. https://doi.org/10.1080/13602381.2017.1366404

Ulfa, A. M., Saputra, A., Yuswardi, \& Nguyen, P. T. (2020). Role of artificial intelligence in pharma science. Journal of Critical Reviews, 7(1), 291-293. https://doi.org/10.31838/jcr.07.01.54

Vo, K. D., Nguyen, P. T., \& Le-Hoai, L. (2019). The difference in personality traits of construction engineers in Vietnam using the kts instrument. Suranaree Journal of Science and Technology, 26(2), 232-239.
Vo, K. D., Nguyen, P. T., Pham, C. P., Huynh, V. D. B., Nguyen, Q. L. H. T. T., Vu, N. B., \& Le, L. P. (2019). Measuring individual job performance of project managers using fuzzy extended analytic method. International Journal of Recent Technology and Engineering, 8(2 Special Issue), 86-90. https://doi. org/10.35940/ijrte.a1379.078219

Vu, D. H., Nguyen, P. T., Nguyen, Q. L. H. T. T., Huynh, V. D. B., Le, Q. T. T., Doan, T. H. D., Le, B. G. P. (2019). Success factors framework for the implementation of e-learning systems in Vietnamese universities. Journal of Critical Reviews, 6(4), 1-6. https://doi.org/10.22159/jcr.06.04.01

Yurdakul, N., Ker-Dincer, M., Vural, Z. B. A., \& Akinci, B. (2008). Searching for excellence in educational communication: The role of IQ, EQ and SQ. Bilig - Turk DunyasI Sosyal Bilimler Dergisi, 45(45), 147-164. 